\title{
Actual and Self-Assessed Financial Literacy among Employees of a South African University
}

Gizelle D. Willows

The University of Cape Town, gizelle.willows@uct.ac.za

Follow this and additional works at: https://digitalcommons.usf.edu/numeracy

Part of the Adult and Continuing Education Commons, Behavioral Economics Commons, and the Finance Commons

\section{Recommended Citation}

Willows, Gizelle D.. "Actual and Self-Assessed Financial Literacy among Employees of a South African University." Numeracy 12, Iss. 1 (2019): Article 11. DOI: https://doi.org/10.5038/1936-4660.12.1.11 


\title{
Actual and Self-Assessed Financial Literacy among Employees of a South African University
}

\author{
Abstract \\ This study examines the level of financial literacy and self-assessed financial literacy amongst members \\ of a South African tertiary institution's retirement fund. Based on surveys of the fund's members, I employ \\ descriptive statistics and multivariate regression analyses to examine differences in financial literacy \\ within and across groups. The results show that, despite working for an employer implementing many \\ best practices identified by financial literacy advocates, respondents from all demographic subgroups \\ possess relatively low levels of financial knowledge. Men, White respondents, and those with a higher \\ cost of employment or higher educational attainment were more likely to have a higher level of financial \\ knowledge. In addition, while most respondents were accurate in their self-assessments of financial \\ literacy, those less accurate self-assessments typically underestimated their abilities. The general \\ accuracy of self-perception implies a self-awareness that can be appropriately exploited to attract less- \\ numerate individuals to training courses. Overall, the findings suggest we might more efficiently target \\ training to subsets of individuals.
}

\section{Keywords}

financial literacy, self-assessment, financial education, gender, race

\section{Creative Commons License}

\section{c) (1) (8)}

This work is licensed under a Creative Commons Attribution-Noncommercial 4.0 License

\section{Cover Page Footnote}

Gizelle D. Willows CA(SA) is an Associate Professor and PhD graduate in finance at the University of Cape Town. Under the mentorship of Professor Terrance Odean, she was a visiting scholar at the Haas School of Business at the University of California (Berkeley) in 2014. She has been the author of a monthly column on personal finance for Accountancy SA for the past four years. Her research interests are retirement savings, personal finance, investment performance, and behavioral finance. 


\section{Introduction}

Against a backdrop of a state old age pension (SOAP) (which alleviates poverty more than it provides for retirement in old age), as well as the fact that the majority of South Africans are finding no alternative but to get into debt to fund consumption (Old Mutual 2013), the importance of personal financial responsibility becomes clear. In particular, the need is well indicated for employment, financial stability, training, and relevant options that can assist in making suitable savings more likely and allowing for such financial responsibility (Xu and Zia 2012).

Unfortunately, a baseline survey of financial knowledge, attitudes, skills, and behaviour of a representative sample of 2,972 adult South Africans finds that many lack basic financial literacy skills (Financial Services Board [FSB] 2012). While the average scores were low, the FSB found a positive correlation between financial literacy and education. The present paper studies financial literacy in a sample of individuals employed at a South African tertiary educational institution. Employees at a tertiary institution have many advantages that might support financial knowledge. One of these is that most of the employees have advanced educational backgrounds. More specifically, close to half of the population tested and those sampled in this study have a tertiary degree greater than an Honours level. Another advantage is that this tertiary institution encourages retirement saving and planning. Because prior research in this field has advocated for employer encouragement such as this, it would be interesting to determine if those factors are indeed sufficient to achieve strong financial literacy throughout the population or if more is required. If the outcome is the latter, knowing which subgroups continue to lag would inform training efforts.

Drawing on established questions used by Lusardi and Mitchell $(2011,2017)$ and Van Rooij et al. (2011), I surveyed members of the South African tertiary institution's retirement fund and calculated scores for both basic and advanced financial knowledge for each member. Having access to differentiating information on the socioeconomic characteristics of these individuals allows identification of characteristics associated with an understanding of financial concepts. This is the primary contribution of the study, and robust statistical testing succeeds in highlighting which subsets of individuals are most in need of improved financial knowledge, after controlling for a range of other factors. Despite the best practices used by the employer, the results point to the same gaps in my sample as found in the South African population as a whole: women, non-whites, and less-educated workers are at a financial literacy disadvantage. Given the hypothesis that financial literacy may assist individuals in planning for retirement (Lusardi and Mitchell 2011), the results of this study suggest a need for greater financial education, even at employers engaged in best practices. 
Furthermore, respondents were asked to self-assess their level of financial knowledge. This information, paired with the calculated financial knowledge score, allows the determination of the accuracy of these assessments and which characteristics are associated with accurate self-assessments.

The study begins by reviewing literature on financial literacy and its influence on financial behaviour. This is followed by a detailed explanation of the method employed in the present paper. The results include both bivariate and multivariate regression analyses. The study ends by presenting conclusions and constructive recommendations to those employed in the task of furthering financial education.

\section{Literature Review}

Many investors lack a basic understanding of financial concepts (Fomero and Monticone 2011), and a sizeable proportion of the population in 14 countries across four continents lack financial knowledge (Atkinson and Messy 2012). Analyses of the level of financial knowledge of individuals will be reviewed, and potential connections with an individual's associated financial behaviour (i.e., their propensity to save for retirement) will be examined.

\section{Financial Literacy}

First, literature regarding the financial literacy of individuals will be considered. Financial literacy includes financial knowledge, awareness, and skills and capability, with the last of these factors being inclusive of financial planning (Xu and Zia 2012).

Age represents one of the most-studied demographic correlates with financial literacy. Lusardi and Mitchell (2011) measure how workers over the age of 50 years make their savings decisions, how they collect information to make such decisions, and whether these workers possess the financial literacy needed to make such decisions. Among older Americans, the authors find financial illiteracy to be prevalent, with only half of respondents being able to answer two basic questions on inflation and compound interest correctly. This finding is supported by the FSB (2016) who assess the state of financial literacy in South Africa and report that individuals over the age of 65 years have the lowest financial literacy scores of all age groups.

In a review of the literature, Xu and Zia (2012) find that the age-dependency seen in FSB (2016) is far from unique. They report similar age-dependence in a number of studies performed in both developed and developing countries. These countries include high-income countries, such as the United States, and low- to middle-income countries, such as Indonesia. Geographically, the studies reviewed by Xu and Zia (2012) span at least 28 countries from each inhabitable continent. The relationship between financial literacy and age they document follows an 
inverted-U shape. Financial literacy improves until about 65 years of age, after which the effects of cognitive deterioration reduces the extent to which older individuals can retain and apply financial knowledge (Atkinson and Messy 2012). Similarly, in the De Nederlandsche Bank (DNB) Household Survey, Van Rooij et al. (2011) note that financial literacy is highest among respondents between the ages of 40 and 60 years, and then declines after the age of 61 years. Van Rooij et al. suggest that financial literacy may initially increase with age due to increased market participation.

Lusardi and Mitchell (2011) report that other demographic characteristics also correlate with financial literacy. They find that minorities and women were most susceptible to having low financial knowledge. This is supported by the FSB (2012) who find that, in a sample of 2,972 representative adult South Africans, women had lower financial literacy than men. In their meta-analysis Xu and Zia (2012) also find women to have lower levels of financial literacy in almost all of the countries investigated.

Education level has also been shown to predict financial literacy. A baseline survey done by the FSB (2012) aims to provide information on the financial knowledge, attitudes, skills, and behaviour of adult South Africans. The findings show that those with lower levels of education have lower financial literacy than those with higher levels of education. In the United States, Lusardi and Mitchell (2011) also show that individuals without a college or high school degree are most likely to display low financial knowledge. Similarly, Agnew and Szykman (2005), studying individuals employed at a mid-size public university in the United States, find that those without a college degree demonstrate less financial knowledge than those with a diploma. These consistent patterns across each study suggest a positive association between basic education and financial literacy.

Considering further socioeconomic differences, Agnew and Szykman (2005) find that married individuals performed better than those who were single. However, individuals with children have lower levels of financial literacy than those without children. In their study, the variable with the most statistically significant effect on the test scores is salary level, which is positively correlated with test scores. Furthermore, investigating financial literacy across studies of a number of countries, Xu and Zia (2012) find that people in higher-income countries perform better on financial literacy tests than those living in lower-income countries.

This literature presents potential correlations between financial literacy and demographic and socioeconomic characteristics such as age, gender, marital status, and salary. The aim of this paper is to assess whether these correlations remain in a sample of highly educated individuals working for an employer implementing many best practices in support of employees' financial planning. Because higher education has been advocated as a measure to improve financial literacy and reduce 
gaps between demographic groups, this study will assess whether this baseline recommendation is indeed sufficient.

Furthermore, the relationship between objectively measured financial knowledge and self-assessed financial knowledge needs to be understood. Agnew and Szykman (2005) note a discrepancy between objectively measured financial knowledge and what people think they know. This suggests a disconnect in which individuals lack the proper self-awareness of their need for financial education. In Agnew and Szykman's (2005) sample of university employees, the extent of this disconnect differs across salary level. Professors have a strong positive correlation between perceived knowledge and test score (0.77), whilst maintenance workers (who are paid lower salaries) exhibit a low correlation (0.17). Given the finding that those with lower salary levels have lower financial literacy, it is hypothesised that the less financially literate the individual, the less likely he or she will identify the need for self-improvement. This important link will be examined in this study.

\section{Influence on Financial Behaviour}

Complex financial decisions need to be made by ordinary consumers on a daily basis, and research has shown that these decisions are often made without the most basic and essential financial knowledge. This finding emphasises the importance of financial literacy. Next, further attention will be given to the influence that financial literacy has on financial behaviour.

Differences in financial literacy are critically important because Atkinson and Messy (2012) find that financial knowledge is correlated with positive financial behaviours including: setting long-term financial goals, having a household budget, paying bills on time, and not borrowing to make ends meet. Similarly, Shefrin (2013) discusses how poor spending and borrowing habits are linked to financial literacy deficiencies.

An individual's level of financial knowledge positively influences his or her financial behaviour. Lusardi and Mitchell (2011) found that those individuals who displayed financial knowledge were more inclined to plan and, furthermore, to succeed in that plan. In high-income countries, financial literacy has been found to be associated with more sophisticated investment behaviour and positively correlated to retirement planning; in lower-income countries, the effects are smaller, yet still positive, and are associated with having a bank account and taking up insurance (Xu and Zia 2012). In another study, Van Rooij et al. (2011) find that individuals with low financial literacy are significantly less likely to invest in stocks, despite these instruments delivering the highest return over the long-term (Smith 2017). Also, Agnew and Szykman (2005) note that individuals with the lowest results on a financial exam are less likely to save enough for retirement. These studies demonstrate a possible association between financial knowledge and planning for retirement, which might result in successful retirement savings 
outcomes. One could argue that poor savings results from inadequate retirement goals. Furthermore, when individuals make an investment choice, it is often one which is unsuitable to accomplish their savings goals (Olsen and Whitman 2007). Attempting to understand the economic importance of financial literacy, Lusardi and Mitchell (2014) reason that the more financially aware an individual is, the better off he or she will be financially on retirement.

The literature reviewed has shown differences in the financial knowledge of subsets of individuals. Furthermore, the importance of increased financial knowledge has been highlighted along with the differences between objectively measured and self-assessed financial knowledge. Given the importance of understanding these concepts, the body of research in these areas is increasing. However, there appears to be a gap in the assessment of individuals who are already displaying some of the advocated factors to improve financial literacy. This study aims to bring new research into this area.

\section{Methods}

The aim of this study is to determine the level of financial knowledge amongst a sample of highly-educated individuals living in South Africa and, in turn, to determine any factors that influence this outcome. Participants were asked questions to determine their level of financial knowledge and self-assessment of such knowledge. Most of the questions used were drawn from previous studies by Lusardi and Mitchell $(2011,2017)$ and Van Rooij et al. (2011). ${ }^{1}$ Appendix A shows the various questions appropriately referenced to the studies from which they were drawn. These questions have been used in a number of studies in a range of countries including: Australia (Agnew et al. 2013), France (Arrondel et al. 2013), Italy (Fomero and Monticone 2011), Japan (Sekita 2011), Romania (Beckmann 2013), Russia (Klapper and Panos 2011), and Switzerland (Brown and Graf 2013).

Questions in this study were divided between "basic" financial literacy questions (assessing compound interest, inflation, and time discounting) and "advanced" financial knowledge. The latter included topics such as the function of the share market, the difference between shares and bonds, how risk diversification works, and the relationship between interest rates and bond prices. Additional questions from Van Rooij et al. (2011) assess an individual's knowledge of financial assets, such as bonds and stocks. The more complex questions require an understanding of financial instruments, such as shares, bonds, and collective investment schemes, as well as other financial concepts.

\footnotetext{
${ }^{1}$ Permission has been granted to use the questions within each of these studies.
} 
The resulting survey was cognitively tested by 11 people (five males and six females of differing ages) to evaluate the wording and design. The suggestions from this testing were analysed and, where appropriate, changes were made to update and improve the original survey questions. The cognitive testing was done in stages; not all 11 testers tested the survey at the same time. This was done to enable each subsequent tester to test any changes suggested by the previous testers. The changes made and the reasoning for each amendment were as follows:

- Changing certain Americanisms to South African terminology (e.g., replacing "firm" with "company" and "stock" with "share").

- Some of the ordered response options were re-ordered from "disagree to agree" to "agree to disagree," as most testers seemed to anticipate that construction.

- The question assessing respondents' self-assessment of financial knowledge from 1-7 was amended to include descriptions for each number (i.e., 1 as "very low," 2 as "low," etc.).

- References in financial knowledge questions to "savings accounts" and "shares" were changed to include "savings accounts / cash" and "shares / equity" to avoid incorrect responses owing to differing terminology.

- References to "moderate" risk companies were changed to "medium" risk companies for more universal/easier language use.

Revision notes for each question are included in the final column of the table in Appendix A.

The data were gathered through a survey using a convenience sample. Staff at the University of Cape Town (UCT) who are members of the UCT Retirement Fund (UCTRF) were targeted. The UCTRF had 3,602 members as of May 31, 2014. These members include all permanent- and fixed-term contract employees, both academic (faculty) and administrative or support staff, who have not yet reached retirement age. Membership in the UCTRF is obligatory and a condition of employment, and all employees automatically become members upon employment. Of these 3,602 members, 3,333 had access to email. The survey was emailed to these members on Tuesday, August 26, 2014 and remained open until the end of that week. The remaining 269 members had hard copies of the survey (with selfaddressed return envelopes) posted to them. A total of 764 responses were received (of which 23 were in hard-copy format). This equated to a total response rate of just over $21 \%$.

The responses were sent to the UCTRF by the respondents. The UCTRF used the staff number provided by each respondent to identify and provide relevant information such as but not limited to: age (as of July 31, 2014), race, gender, cost 
of employment ${ }^{2}$ (COE), and highest qualification level. The highest level of qualification of each respondent was ranked and placed in four categories as follows: (1) highest qualification level at the secondary schooling level or lower, (2) highest qualification level greater than secondary schooling, inclusive of postgraduate diploma, but less than an Honours tertiary degree, (3) highest qualification level at a minimum of a tertiary Honours degree, and (4) unknown. However, the UCTRF was unable to give information for 11 of the members owing to incorrect staff numbers as provided by these respondents. Consequently, these 11 members were excluded from any further analysis, resulting in a final sample of 753 members. Nevertheless, the sample remained large enough to apply the central limit theorem in statistical testing.

Table 1

Total Population vs. Sampled Respondents

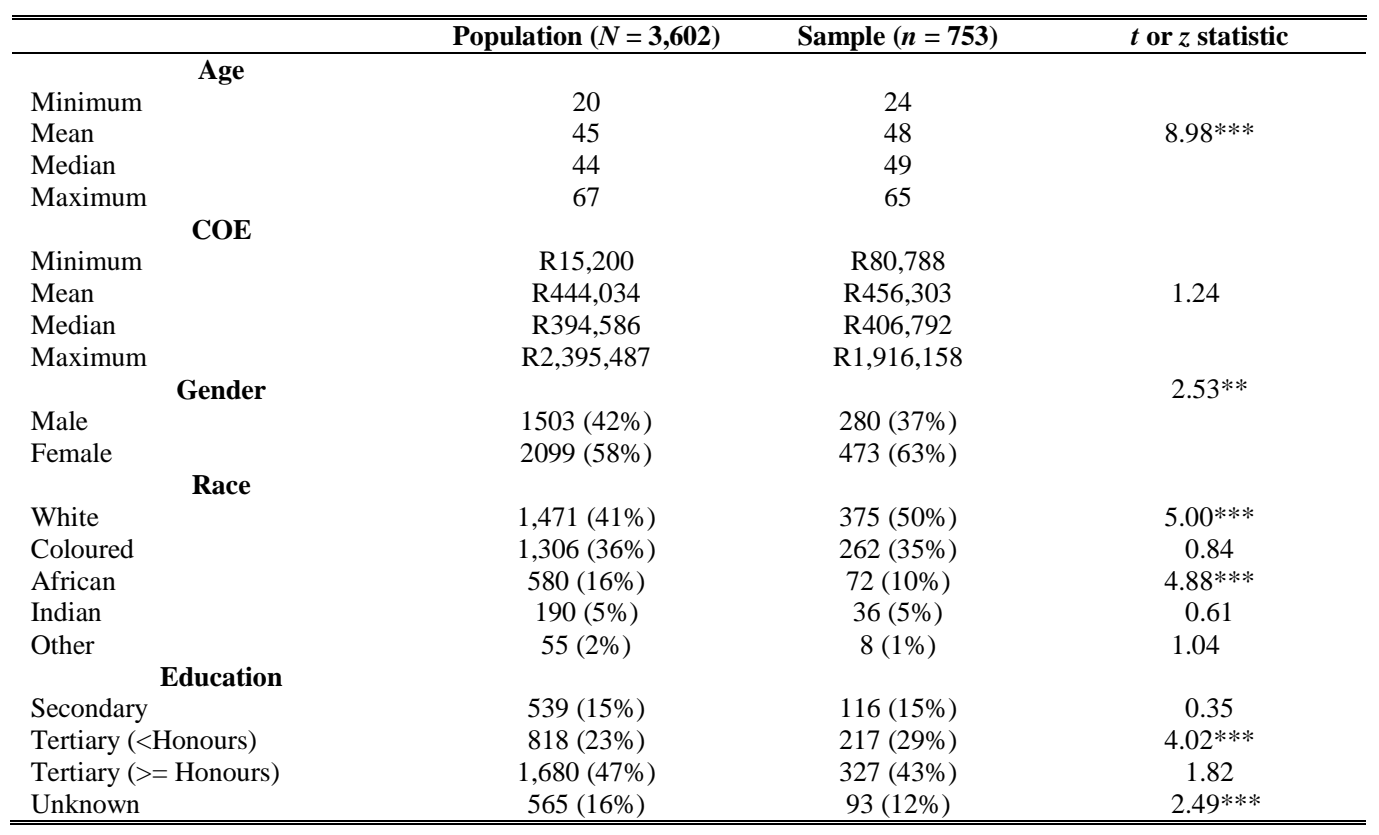

$* * * p<0.01, * * p<0.05, * p<0.1$

Table 1 presents summary statistics for the total population of individuals in the retirement system and the sample of respondents. The final column presents the $t$ and $z$ statistics associated with the null hypotheses that the means/proportions seen in the respondent sample equal those in the population.

2 The total amount paid to an employee, inclusive of all salaries, wages, commissions, fringe benefits, and any employer payments for medical insurance and pension funds. 
Table 1 shows that the subgroup of sampled respondents is mostly representative of the total population of fund participants. However, given the sample size it is not surprising that some differences are statistically significant. The respondents are slightly older, more likely to be White, less likely to be African, and more likely to hold a tertiary degree. (Within the race subset, respondents are classified as being either White, Coloured (i.e., of mixed-race descent), African, Indian, or Other, per the data obtained from the UCTRF.) The differences by age and gender are deemed to be of practically modest size. However, to account for potential selection bias, the analysis described below was repeated making an adjustment for the different response rates by race and education and no substantive difference was found.

\section{Results}

This section will examine the level of actual and perceived financial knowledge and their correlation. Then, a multivariate regression analysis is performed to determine the factors influencing financial knowledge.

\section{Basic and Advanced Financial Literacy}

The basic financial knowledge questions tested simple concepts that form the basis of basic financial decision-making and transactions. Table 2 shows the percentage of correct answers for the total sample of respondents on each of the four questions. Table 3 shows the distribution of the number of correct answers on the four basic financial knowledge questions.

Table 2

Percentage of Correct Answers on Each Basic Financial Knowledge Question ( $n=753)$

\begin{tabular}{lcccc}
\hline \hline & Numeracy & Inflation & $\begin{array}{c}\text { Time Value } \\
\text { of Money }\end{array}$ & $\begin{array}{c}\text { Money } \\
\text { Illusion }\end{array}$ \\
\hline Correct & $87 \%$ & $83 \%$ & $77 \%$ & $62 \%$ \\
Incorrect & $6 \%$ & $6 \%$ & $16 \%$ & $34 \%$ \\
Do not know & $7 \%$ & $11 \%$ & $6 \%$ & $4 \%$ \\
\hline \hline
\end{tabular}

Table 3

Distribution of the Number of Correct Answers on Four Basic Financial Knowledge Questions ( $n=753)$

\begin{tabular}{lcccccc}
\hline \hline & None & One & Two & Three & All Four & Mean \\
\hline Correct & $4 \%$ & $7 \%$ & $13 \%$ & $28 \%$ & $48 \%$ & 3.1 \\
Incorrect & $55 \%$ & $30 \%$ & $12 \%$ & $3 \%$ & $0 \%$ & 0.63 \\
Do not know & $83 \%$ & $11 \%$ & $4 \%$ & $1 \%$ & $1 \%$ & 0.27 \\
\hline \hline
\end{tabular}

Table 2 shows that most respondents understand the effects of interest and inflation. The numeracy question, which asked about the basic mechanics of interest in a bank account, received the highest number of correct responses $(87 \%)$ while $83 \%$ correctly answered the basic question concerning inflation. However, 
the percentage of correct answers on these questions were not as high as the $93 \%$ and $91 \%$ scored by respondents in Lusardi and Mitchell's (2017) U.S.-based study. While success rates on individual questions are relatively high, the results presented in Table 3 show that less than half of the respondents were able to answer all four basic financial knowledge questions correctly.

Table 4 shows the percentage of correct answers achieved by respondents in subsets defined by socioeconomic characteristics: age, gender, race, education level, marital status, and cost of employment. White respondents and those respondents with a higher qualification level received the highest number of correct answers across all four questions.

Table 4

Percentage of Correct Answers on Each Basic Financial Knowledge Question, by Socioeconomic and Demographic Subgroup

\begin{tabular}{|c|c|c|c|c|}
\hline & Numeracy & Inflation & $\begin{array}{c}\text { Time Value } \\
\text { of Money }\end{array}$ & $\begin{array}{c}\text { Money } \\
\text { Illusion }\end{array}$ \\
\hline \multicolumn{5}{|c|}{ Age $<=50(n=416)$} \\
\hline Correct & $88 \%$ & $79 \%$ & $76 \%$ & $66 \%$ \\
\hline Incorrect & $6 \%$ & $7 \%$ & $18 \%$ & $32 \%$ \\
\hline Do not know & $6 \%$ & $14 \%$ & $6 \%$ & $2 \%$ \\
\hline \multicolumn{5}{|c|}{ Age $>50(n=337)$} \\
\hline Correct & $86 \%$ & $89 \%$ & $79 \%$ & $58 \%$ \\
\hline Incorrect & $7 \%$ & $4 \%$ & $14 \%$ & $37 \%$ \\
\hline Do not know & $7 \%$ & $7 \%$ & $7 \%$ & $5 \%$ \\
\hline \multicolumn{5}{|c|}{ Male $(n=280)$} \\
\hline Correct & $90 \%$ & $89 \%$ & $81 \%$ & $71 \%$ \\
\hline Incorrect & $5 \%$ & $4 \%$ & $15 \%$ & $27 \%$ \\
\hline Do not know & $5 \%$ & $7 \%$ & $4 \%$ & $2 \%$ \\
\hline \multicolumn{5}{|c|}{ Female $(n=473)$} \\
\hline Correct & $86 \%$ & $80 \%$ & $75 \%$ & $57 \%$ \\
\hline Incorrect & $7 \%$ & $7 \%$ & $18 \%$ & $38 \%$ \\
\hline Do not know & $7 \%$ & $13 \%$ & $7 \%$ & $5 \%$ \\
\hline \multicolumn{5}{|c|}{ Race $=$ White $(n=375)$} \\
\hline Correct & $94 \%$ & $96 \%$ & $88 \%$ & $75 \%$ \\
\hline Incorrect & $4 \%$ & $2 \%$ & $9 \%$ & $22 \%$ \\
\hline Do not know & $2 \%$ & $2 \%$ & $3 \%$ & $3 \%$ \\
\hline \multicolumn{5}{|c|}{ Race $=$ Coloured $(n=262)$} \\
\hline Correct & $83 \%$ & $75 \%$ & $68 \%$ & $50 \%$ \\
\hline Incorrect & $9 \%$ & $9 \%$ & $25 \%$ & $45 \%$ \\
\hline Do not know & $8 \%$ & $16 \%$ & $7 \%$ & $5 \%$ \\
\hline \multicolumn{5}{|c|}{ Race $=$ African $(n=72)$} \\
\hline Correct & $65 \%$ & $46 \%$ & $53 \%$ & $38 \%$ \\
\hline Incorrect & $8 \%$ & $14 \%$ & $32 \%$ & $58 \%$ \\
\hline Do not know & $27 \%$ & $40 \%$ & $15 \%$ & $4 \%$ \\
\hline \multicolumn{5}{|c|}{ Race $=$ Indian $(n=36)$} \\
\hline Correct & $89 \%$ & $92 \%$ & $78 \%$ & $67 \%$ \\
\hline Incorrect & $8 \%$ & $3 \%$ & $11 \%$ & $30 \%$ \\
\hline Do not know & $3 \%$ & $5 \%$ & $11 \%$ & $3 \%$ \\
\hline
\end{tabular}


Table 4 (cont.)

Percentage of Correct Answers on Each Basic Financial Knowledge Question, by Socioeconomic and Demographic Subgroup

\begin{tabular}{|c|c|c|c|c|}
\hline & "Numeracy & Inflation & $\begin{array}{c}\text { Time Value } \\
\text { of Money }\end{array}$ & $\begin{array}{l}\text { Money } \\
\text { Illusion }\end{array}$ \\
\hline \multicolumn{5}{|c|}{ Race $=$ Other $(n=8)$} \\
\hline Correct & $75 \%$ & $100 \%$ & $88 \%$ & $63 \%$ \\
\hline Incorrect & $13 \%$ & $0 \%$ & $13 \%$ & $25 \%$ \\
\hline Do not know & $13 \%$ & $0 \%$ & $0 \%$ & $130 \%$ \\
\hline \multicolumn{5}{|c|}{$\begin{array}{c}\text { Education }=\text { Secondary } \\
\quad(n=116)\end{array}$} \\
\hline Correct & $78 \%$ & $75 \%$ & $70 \%$ & $51 \%$ \\
\hline Incorrect & $11 \%$ & $7 \%$ & $22 \%$ & $44 \%$ \\
\hline Do not know & $11 \%$ & $18 \%$ & $8 \%$ & $5 \%$ \\
\hline \multicolumn{5}{|c|}{$\begin{array}{l}\text { Education = Tertiary } \\
(<\text { Honours })(n=217)\end{array}$} \\
\hline Correct & $85 \%$ & $78 \%$ & $70 \%$ & $53 \%$ \\
\hline Incorrect & $7 \%$ & $9 \%$ & $22 \%$ & $42 \%$ \\
\hline Do not know & $8 \%$ & $13 \%$ & $8 \%$ & $5 \%$ \\
\hline \multicolumn{5}{|c|}{$\begin{array}{l}\text { Education }=\text { Tertiary } \\
(>=\text { Honours })(n=327)\end{array}$} \\
\hline Correct & $94 \%$ & $94 \%$ & $89 \%$ & $80 \%$ \\
\hline Incorrect & $4 \%$ & $2 \%$ & $8 \%$ & $18 \%$ \\
\hline Do not know & $2 \%$ & $4 \%$ & $3 \%$ & $2 \%$ \\
\hline \multicolumn{5}{|c|}{$\begin{array}{c}\text { Education }=\text { Unknown } \\
(n=93)\end{array}$} \\
\hline Correct & $84 \%$ & $68 \%$ & $62 \%$ & $36 \%$ \\
\hline Incorrect & $5 \%$ & $10 \%$ & $28 \%$ & $59 \%$ \\
\hline Do not know & $11 \%$ & $22 \%$ & $10 \%$ & $5 \%$ \\
\hline \multicolumn{5}{|c|}{ Married $(n=526)$} \\
\hline Correct & $89 \%$ & $85 \%$ & $78 \%$ & $65 \%$ \\
\hline Incorrect & $5 \%$ & $5 \%$ & $16 \%$ & $32 \%$ \\
\hline Do not know & $6 \%$ & $10 \%$ & $6 \%$ & $3 \%$ \\
\hline \multicolumn{5}{|c|}{ Single $(n=227)$} \\
\hline Correct & $84 \%$ & $80 \%$ & $75 \%$ & $57 \%$ \\
\hline Incorrect & $8 \%$ & $7 \%$ & $18 \%$ & $39 \%$ \\
\hline $\begin{array}{l}\text { Do not know } \\
\text { COE }<\mathbf{R 4 0 0}\end{array}$ & $8 \%$ & $13 \%$ & $7 \%$ & $4 \%$ \\
\hline Correct & $80 \%$ & $70 \%$ & $64 \%$ & $47 \%$ \\
\hline Incorrect & $9 \%$ & $10 \%$ & $26 \%$ & $47 \%$ \\
\hline $\begin{array}{l}\text { Do not know } \\
\text { COE }>\text { R400 }\end{array}$ & $11 \%$ & $20 \%$ & $10 \%$ & $6 \%$ \\
\hline Correct & $94 \%$ & $96 \%$ & $90 \%$ & $22 \%$ \\
\hline Incorrect & $4 \%$ & $2 \%$ & $8 \%$ & $76 \%$ \\
\hline Do not know & $2 \%$ & $2 \%$ & $2 \%$ & $2 \%$ \\
\hline
\end{tabular}

The results for the advanced financial knowledge questions are shown in Tables 5 and 6 . These questions were more sophisticated than the basic questions and tested concepts regarding the share market, collective investment schemes, bonds, and risk. While many respondents showed strong basic financial knowledge, only a few showed mastery of advanced financial knowledge. 
Table 5

Percentage of Correct Answers on Each Advanced Financial Knowledge Question ( $n=753)$

\begin{tabular}{lccc}
\hline \hline & Correct & Incorrect & Do not know \\
\hline Function of share market & $60 \%$ & $17 \%$ & $23 \%$ \\
Knowledge of shares & $78 \%$ & $12 \%$ & $9 \%$ \\
Knowledge of collective & $57 \%$ & $16 \%$ & $26 \%$ \\
investment schemes & & & \\
Knowledge of bonds & $49 \%$ & $20 \%$ & $30 \%$ \\
Long-period returns & $64 \%$ & $21 \%$ & $15 \%$ \\
Highest variability & $69 \%$ & $12 \%$ & $18 \%$ \\
Risk diversification & $83 \%$ & $9 \%$ & $8 \%$ \\
Bond principles & $21 \%$ & $34 \%$ & $45 \%$ \\
\hline \hline
\end{tabular}

Table 6

Distribution of the Number of Correct Answers on Eight Advanced Financial Knowledge Questions $(n=753)$

\begin{tabular}{lccc}
\hline \hline & Correct & Incorrect & Do not know \\
\hline None & $3 \%$ & $28 \%$ & $35 \%$ \\
One & $5 \%$ & $33 \%$ & $24 \%$ \\
Two & $9 \%$ & $21 \%$ & $13 \%$ \\
Three & $11 \%$ & $10 \%$ & $11 \%$ \\
Four & $14 \%$ & $4 \%$ & $7 \%$ \\
Five & $17 \%$ & $2 \%$ & $6 \%$ \\
Six & $14 \%$ & $1 \%$ & $4 \%$ \\
Seven & $19 \%$ & $0 \%$ & $1 \%$ \\
All Eight & $9 \%$ & $0 \%$ & $1 \%$ \\
Mean & 4.8 & 1.4 & 1.8 \\
\hline \hline
\end{tabular}

More than half of the respondents have some knowledge of the function of the share market, shares, collective investment schemes, long-period returns, variability of returns, and how risk diversification works. However, an analysis of the responses with respect to knowledge of and principles relating to bonds shows less of an understanding. Nearly half of the respondents (45\%) responded that they did not know the answer to the bond principles question (which tested the link between bond prices and interest rates). Furthermore, only $9 \%$ of respondents could answer all the advanced financial knowledge questions correctly.

Further analysis across socioeconomic subsets is shown in Table 7. Similar to the output in Table 4 pertaining to basic financial literacy, White respondents and those with a higher qualification level received the highest number of correct answers across the majority of the advanced financial knowledge questions. Furthermore, men and those with a higher cost of employment also answered a larger proportion of the questions correctly. 
Numeracy, Vol. 12 [2019], Iss. 1, Art. 11

Table 7

Percentage of Correct Answers on Each Advanced Financial Knowledge Question, by Socioeconomic and Demographic Subgroup

\begin{tabular}{|c|c|c|c|c|c|c|c|c|}
\hline & $\begin{array}{c}\text { Function } \\
\text { of Share } \\
\text { market }\end{array}$ & $\begin{array}{c}\text { Knowledge } \\
\text { of Shares }\end{array}$ & $\begin{array}{l}\text { Knowledge of } \\
\text { Collective } \\
\text { Investment } \\
\text { Schemes }\end{array}$ & $\begin{array}{l}\text { Knowledge } \\
\text { of Bonds }\end{array}$ & $\begin{array}{l}\text { Long-period } \\
\text { Returns }\end{array}$ & $\begin{array}{c}\text { Highest } \\
\text { Variability }\end{array}$ & $\begin{array}{c}\text { Risk } \\
\text { Diversification }\end{array}$ & $\begin{array}{c}\text { Bond } \\
\text { Principles }\end{array}$ \\
\hline \multicolumn{9}{|c|}{ Age $<=50(n=416)$} \\
\hline Correct & $57 \%$ & $80 \%$ & $51 \%$ & $45 \%$ & $58 \%$ & $66 \%$ & $79 \%$ & $23 \%$ \\
\hline Incorrect & $16 \%$ & $11 \%$ & $17 \%$ & $23 \%$ & $26 \%$ & $13 \%$ & $12 \%$ & $33 \%$ \\
\hline Do not know & $27 \%$ & $9 \%$ & $32 \%$ & $32 \%$ & $16 \%$ & $21 \%$ & $9 \%$ & $44 \%$ \\
\hline \multicolumn{9}{|c|}{ Age $>50 \quad(n=337)$} \\
\hline Correct & $64 \%$ & $77 \%$ & $64 \%$ & $55 \%$ & $72 \%$ & $73 \%$ & $88 \%$ & $18 \%$ \\
\hline Incorrect & $18 \%$ & $13 \%$ & $16 \%$ & $17 \%$ & $15 \%$ & $11 \%$ & $7 \%$ & $36 \%$ \\
\hline Do not know & $18 \%$ & $10 \%$ & $20 \%$ & $28 \%$ & $13 \%$ & $16 \%$ & $5 \%$ & $46 \%$ \\
\hline \multicolumn{9}{|c|}{ Male $(n=280)$} \\
\hline Correct & $73 \%$ & $86 \%$ & $63 \%$ & $66 \%$ & $72 \%$ & $78 \%$ & $89 \%$ & $26 \%$ \\
\hline Incorrect & $12 \%$ & $9 \%$ & $17 \%$ & $16 \%$ & $20 \%$ & $10 \%$ & $7 \%$ & $37 \%$ \\
\hline Do not know & $15 \%$ & $5 \%$ & $20 \%$ & $18 \%$ & $8 \%$ & $12 \%$ & $4 \%$ & $37 \%$ \\
\hline \multicolumn{9}{|c|}{ Female $(n=473)$} \\
\hline Correct & $53 \%$ & $74 \%$ & $54 \%$ & $39 \%$ & $60 \%$ & $64 \%$ & $80 \%$ & $17 \%$ \\
\hline Incorrect & $20 \%$ & $14 \%$ & $16 \%$ & $23 \%$ & $21 \%$ & $14 \%$ & $11 \%$ & $33 \%$ \\
\hline Do not know & $27 \%$ & $12 \%$ & $30 \%$ & $38 \%$ & $19 \%$ & $22 \%$ & $9 \%$ & $50 \%$ \\
\hline \multicolumn{9}{|c|}{ Race $=$ White $(n=375)$} \\
\hline Correct & $78 \%$ & $83 \%$ & $70 \%$ & $66 \%$ & $78 \%$ & $80 \%$ & $96 \%$ & $23 \%$ \\
\hline Incorrect & $13 \%$ & $11 \%$ & $12 \%$ & $10 \%$ & $10 \%$ & $7 \%$ & $2 \%$ & $33 \%$ \\
\hline Do not know & $9 \%$ & $6 \%$ & $18 \%$ & $24 \%$ & $12 \%$ & $13 \%$ & $2 \%$ & $44 \%$ \\
\hline \multicolumn{9}{|c|}{ Race $=$ Coloured $(n=262)$} \\
\hline Correct & $39 \%$ & $74 \%$ & $43 \%$ & $27 \%$ & $49 \%$ & $57 \%$ & $69 \%$ & $17 \%$ \\
\hline Incorrect & $24 \%$ & $15 \%$ & $25 \%$ & $34 \%$ & $32 \%$ & $18 \%$ & $17 \%$ & $38 \%$ \\
\hline Do not know & $37 \%$ & $11 \%$ & $32 \%$ & $39 \%$ & $19 \%$ & $25 \%$ & $14 \%$ & $45 \%$ \\
\hline \multicolumn{9}{|c|}{ Race $=$ African $(n=72)$} \\
\hline Correct & $42 \%$ & $72 \%$ & $40 \%$ & $44 \%$ & $44 \%$ & $55 \%$ & $60 \%$ & $26 \%$ \\
\hline Incorrect & $21 \%$ & $14 \%$ & $13 \%$ & $31 \%$ & $43 \%$ & $21 \%$ & $23 \%$ & $32 \%$ \\
\hline Do not know & $37 \%$ & $14 \%$ & $47 \%$ & $25 \%$ & $13 \%$ & $24 \%$ & $17 \%$ & $42 \%$ \\
\hline
\end{tabular}


Willows: Financial Literacy among Employees of a South African University

Table 7 (cont.)

Percentage of Correct Answers on Each Advanced Financial Knowledge Question, by Socioeconomic and Demographic Subgroup

\begin{tabular}{|c|c|c|c|c|c|c|c|c|}
\hline & $\begin{array}{c}\text { Function of } \\
\text { Share } \\
\text { market }\end{array}$ & $\begin{array}{l}\text { Knowledge of } \\
\text { Shares }\end{array}$ & $\begin{array}{l}\text { Knowledge of } \\
\text { Collective } \\
\text { Investment } \\
\text { Schemes } \\
\end{array}$ & $\begin{array}{l}\text { Knowledge of } \\
\text { Bonds }\end{array}$ & $\begin{array}{l}\text { Long-period } \\
\text { Returns }\end{array}$ & $\begin{array}{c}\text { Highest } \\
\text { Variability }\end{array}$ & $\begin{array}{c}\text { Risk } \\
\text { Diversification }\end{array}$ & $\begin{array}{c}\text { Bond } \\
\text { Principles }\end{array}$ \\
\hline \multicolumn{9}{|c|}{ Race $=$ Indian $(n=36)$} \\
\hline Correct & $58 \%$ & $75 \%$ & $53 \%$ & $39 \%$ & $64 \%$ & $72 \%$ & $83.3 \%$ & $19 \%$ \\
\hline Incorrect & $6 \%$ & $8 \%$ & $17 \%$ & $19 \%$ & $14 \%$ & $11 \%$ & $8.3 \%$ & $31 \%$ \\
\hline Do not know & $36 \%$ & $17 \%$ & $30 \%$ & $42 \%$ & $22 \%$ & $17 \%$ & $8.3 \%$ & $50 \%$ \\
\hline \multicolumn{9}{|c|}{$\begin{array}{c}\text { Race }= \\
\text { Other }(n=8)\end{array}$} \\
\hline Correct & $75 \%$ & $75 \%$ & $75 \%$ & $63 \%$ & $88 \%$ & $50 \%$ & $100 \%$ & $0 \%$ \\
\hline Incorrect & $13 \%$ & $13 \%$ & $13 \%$ & $13 \%$ & $0 \%$ & $13 \%$ & $0 \%$ & $25 \%$ \\
\hline Do not know & $13 \%$ & $13 \%$ & $13 \%$ & $25 \%$ & $13 \%$ & $38 \%$ & $0 \%$ & $75 \%$ \\
\hline \multicolumn{9}{|c|}{$\begin{array}{c}\text { Education }= \\
\text { Secondary }(n=116)\end{array}$} \\
\hline Correct & $48 \%$ & $81 \%$ & $50 \%$ & $40 \%$ & $54 \%$ & $61 \%$ & $75 \%$ & $19 \%$ \\
\hline Incorrect & $19 \%$ & $10 \%$ & $18 \%$ & $26 \%$ & $29 \%$ & $21 \%$ & $10 \%$ & $34 \%$ \\
\hline Do not know & $33 \%$ & $9 \%$ & $32 \%$ & $34 \%$ & $18 \%$ & $18 \%$ & $15 \%$ & $47 \%$ \\
\hline \multicolumn{9}{|c|}{$\begin{array}{l}\text { Education }=\text { Tertiary } \\
(<\text { Honours })(n=217)\end{array}$} \\
\hline Correct & $54 \%$ & $73 \%$ & $54 \%$ & $42 \%$ & $57 \%$ & $60 \%$ & $78 \%$ & $19 \%$ \\
\hline Incorrect & $18 \%$ & $13.5 \%$ & $18 \%$ & $27 \%$ & $25 \%$ & $17 \%$ & $15 \%$ & $34 \%$ \\
\hline Do not know & $28 \%$ & $13.5 \%$ & $28 \%$ & $31 \%$ & $18 \%$ & $23 \%$ & $7 \%$ & $47 \%$ \\
\hline \multicolumn{9}{|c|}{$\begin{array}{l}\text { Education }=\text { Tertiary } \\
(>=\text { Honours })(n=327)\end{array}$} \\
\hline Correct & $78 \%$ & $84 \%$ & $68 \%$ & $66 \%$ & $75 \%$ & $81 \%$ & $95 \%$ & $23 \%$ \\
\hline Incorrect & $11 \%$ & $11 \%$ & $12 \%$ & $10 \%$ & $13 \%$ & $5 \%$ & $2 \%$ & $31 \%$ \\
\hline Do not know & $11 \%$ & $5 \%$ & $20 \%$ & $24 \%$ & $12 \%$ & $14 \%$ & $3 \%$ & $46 \%$ \\
\hline \multicolumn{9}{|c|}{$\begin{array}{c}\text { Education }=\text { Unknown } \\
(n=93)\end{array}$} \\
\hline Correct & $25 \%$ & $66 \%$ & $33 \%$ & $21 \%$ & $58 \%$ & $59 \%$ & $60 \%$ & $17 \%$ \\
\hline Incorrect & $31 \%$ & $17 \%$ & $27 \%$ & $33 \%$ & $28 \%$ & $19 \%$ & $23 \%$ & $46 \%$ \\
\hline Do not know & $44 \%$ & $17 \%$ & $40 \%$ & $46 \%$ & $14 \%$ & $22 \%$ & $17 \%$ & $37 \%$ \\
\hline
\end{tabular}


Numeracy, Vol. 12 [2019], Iss. 1, Art. 11

Table 7 (cont.)

Percentage of Correct Answers on Each Advanced Financial Knowledge Question, by Socioeconomic and Demographic Subgroup

\begin{tabular}{|c|c|c|c|c|c|c|c|c|}
\hline & $\begin{array}{c}\text { Function of } \\
\text { Share market }\end{array}$ & $\begin{array}{l}\text { Knowledge } \\
\text { of Shares }\end{array}$ & $\begin{array}{c}\text { Knowledge of } \\
\text { Collective } \\
\text { Investment } \\
\text { Schemes } \\
\end{array}$ & $\begin{array}{c}\begin{array}{c}\text { Knowledge of } \\
\text { Bonds }\end{array} \\
\end{array}$ & $\begin{array}{c}\text { Long-period } \\
\text { Returns }\end{array}$ & $\begin{array}{c}\text { Highest } \\
\text { Variability }\end{array}$ & $\begin{array}{c}\text { Risk } \\
\text { Diversification }\end{array}$ & $\begin{array}{c}\text { Bond } \\
\text { Principles }\end{array}$ \\
\hline \multicolumn{9}{|c|}{ Married $(n=526)$} \\
\hline Correct & $62 \%$ & $79 \%$ & $56 \%$ & $50 \%$ & $63 \%$ & $69 \%$ & $84 \%$ & $20 \%$ \\
\hline Incorrect & $16 \%$ & $13 \%$ & $19 \%$ & $20 \%$ & $21 \%$ & $12 \%$ & $9 \%$ & $34 \%$ \\
\hline Do not know & $22 \%$ & $8 \%$ & $25 \%$ & $30 \%$ & $16 \%$ & $19 \%$ & $7 \%$ & $46 \%$ \\
\hline \multicolumn{9}{|c|}{ Single $(n=227)$} \\
\hline Correct & $55 \%$ & $77 \%$ & $59 \%$ & $47 \%$ & $66 \%$ & $69 \%$ & $82 \%$ & $22 \%$ \\
\hline Incorrect & $20 \%$ & $10 \%$ & $11 \%$ & $21 \%$ & $20 \%$ & $15 \%$ & $10 \%$ & $34 \%$ \\
\hline Do not know & $25 \%$ & $13 \%$ & $30 \%$ & $32 \%$ & $14 \%$ & $16 \%$ & $8 \%$ & $44 \%$ \\
\hline \multicolumn{9}{|c|}{$\begin{array}{c}\text { COE }<\text { R400k p.a. } \\
(n=359)\end{array}$} \\
\hline Correct & $41 \%$ & $71 \%$ & $44 \%$ & $30 \%$ & $51 \%$ & $59 \%$ & $69 \%$ & $19 \%$ \\
\hline Incorrect & $23 \%$ & $14 \%$ & $21 \%$ & $30 \%$ & $29 \%$ & $18 \%$ & $17 \%$ & $35 \%$ \\
\hline Do not know & $36 \%$ & $15 \%$ & $35 \%$ & $40 \%$ & $20 \%$ & $23 \%$ & $14 \%$ & $46 \%$ \\
\hline \multicolumn{9}{|c|}{$\underset{\substack{\text { COE } \\
(n=394)}}{\text { R400k p.a. }}$} \\
\hline Correct & $77 \%$ & $85 \%$ & $69 \%$ & $66 \%$ & $76 \%$ & $79 \%$ & $95 \%$ & $22 \%$ \\
\hline Incorrect & $11.5 \%$ & $11 \%$ & $13 \%$ & $12 \%$ & $13 \%$ & $7 \%$ & $3 \%$ & $33 \%$ \\
\hline Do not know & $11.5 \%$ & $4 \%$ & $18 \%$ & $22 \%$ & $11 \%$ & $14 \%$ & $2 \%$ & $45 \%$ \\
\hline
\end{tabular}




\section{Financial Knowledge Score}

A financial knowledge score was calculated for each respondent by taking the count of correct answers divided by the total of 15 questions. A single-factor ANOVA determined whether the subgroups of each variable share a common mean. Table 8 presents the mean, median, and standard deviation of the calculated financial knowledge score, along with the $\mathrm{F}$ statistic from the ANOVA analysis testing equality of means across subgroups.

Table 8

Financial Knowledge Score by Socioeconomic and Demographic Subgroup

\begin{tabular}{|c|c|c|c|c|}
\hline & "Mean & Median & Std. Dev. & FF Statistic \\
\hline Total sample $(n=753)$ & $63 \%$ & $67 \%$ & $23 \%$ & \\
\hline Age & & & & $8.37 * * *$ \\
\hline Age $<=50(n=416)^{\circ}$ & $60 \%$ & $60 \%$ & $24 \%$ & \\
\hline Age $>50(n=337)$ & $65 \%$ & $67 \%$ & $23 \%$ & \\
\hline Gender & & & & $54.85 * * *$ \\
\hline Male $(n=280)$ & $70 \%$ & $73 \%$ & $22 \%$ & \\
\hline Female $(n=473)$ & $58 \%$ & $60 \%$ & $23 \%$ & \\
\hline Race & & & & $53.12 * * *$ \\
\hline White $(n=375)$ & $73 \%$ & $80 \%$ & $20 \%$ & \\
\hline Coloured $(n=262)$ & $52 \%$ & $53 \%$ & $21 \%$ & \\
\hline African $(n=72)$ & $47 \%$ & $43 \%$ & $23 \%$ & \\
\hline Indian $(n=36)$ & $61 \%$ & $60 \%$ & $23 \%$ & \\
\hline Other $(n=8)$ & $67 \%$ & $73 \%$ & $17 \%$ & \\
\hline Education & & & & $52.78 * * * 3$ \\
\hline Secondary $(n=116)$ & $55 \%$ & $60 \%$ & $21 \%$ & \\
\hline $\begin{array}{l}\text { Tertiary } \\
(<\text { Honours })(n=217)\end{array}$ & $57 \%$ & $60 \%$ & $24 \%$ & \\
\hline $\begin{array}{l}\text { Tertiary } \\
(>=\text { Honours })(n=327)\end{array}$ & $73 \%$ & $80 \%$ & $20 \%$ & \\
\hline Unknown $(n=93)$ & $46 \%$ & $47 \%$ & $19 \%$ & \\
\hline Marital Status & & & & 1.55 \\
\hline Married $(n=526)$ & $63 \%$ & $67 \%$ & $23 \%$ & \\
\hline Single $(n=227)$ & $61 \%$ & $67 \%$ & $24 \%$ & \\
\hline Cost of Employment & & & & 223.56 *** \\
\hline$<$ R400 000 p.a. $(n=359)$ & $51 \%$ & $53 \%$ & $22 \%$ & \\
\hline$>$ R400 000 p.a. $(n=394)$ & $73 \%$ & $80 \%$ & $19 \%$ & \\
\hline
\end{tabular}

The mean financial knowledge score for the total sample is $63 \%$ (median $67 \%$ ). When analysed across socioeconomic characteristics, it is noticeable that respondents over the age of 50 years, male respondents, White respondents, those respondents with high qualification levels, and those respondents with higher earnings have mean scores (ranging between 65\% and 73\%) which are higher than the average. (In each of these cases, the null hypothesis of equal means across subgroups can be rejected at the $1 \%$ significance level.)

3 The "unknown" education level is excluded in the ANOVA analysis. Therefore, the F statistic is for the difference in means amongst the three remaining education level groups only. 
The lowest average score is found among African respondents with a mean score of $47 \%$ (median $43 \%$ ). The noticeable racial divide in financial knowledge scores might be caused by a variety of factors. One possible explanation is the racially exclusionist education policies implemented during the apartheid years in South Africa. During this time many non-White South Africans might have experienced substandard schooling or have grown up in households with parents who might never have had a formal qualification or exposure to finance and financial instruments (Spaull 2015). Furthermore, the mean COE of African respondents of R299,694 is substantially less than the average mean among all respondents of R456,302. Given that income has been found to influence financial literacy (Xu and Zia 2012, Agnew and Szykman 2005), this might be another explanation for the lower financial knowledge score of this cohort. However, because these variables are colinear, a multivariate analysis (below) should be considered before speculating about causal connections.

\section{Factors Influencing Financial Knowledge}

The univariate analyses in the previous section may be pointing to distinct causal channels or merely strong correlations between multiple socioeconomic and demographic markers, only one of which is key to determining financial literacy. To explore these alternative hypotheses, an ordinary least squares (OLS) regression was performed to determine whether any factors are predictive in determining an individual's level of financial knowledge, controlling for other socioeconomic and demographic variables. ${ }^{4}$ The regression analysis was performed using robust standard errors to account for heteroskedasticity. The reference groups for racial categories and education level will be the White and secondary level of qualification, respectively.

Specifically, I fit the following model using OLS:

$$
\begin{aligned}
& \text { Financial knowledge score } \\
& \qquad \begin{array}{l}
\quad \beta_{0}+\beta_{1} \text { Age }+\beta_{2} \text { Age }{ }^{2}+\beta_{3} \text { Marital status }+\beta_{4} \text { Gender } \\
+\beta_{5-9} \text { Racial grouping dummies }+\beta_{10} \text { Log of cost of employment } \\
+\beta_{11-14} \text { Level of qualification dummies }+\mu
\end{array}
\end{aligned}
$$

where $\beta_{0}$ is the intercept, $\beta_{1-14}$ are the parameters associated with the independent variables, and $\mu$ refers to the factors that are not included in the model. The results are shown in Table 9.

\footnotetext{
${ }^{4}$ Given that the financial knowledge score for each respondent can be viewed as a continuous variable and an ordinal variable, both an OLS and an ordered logistic regression analysis was performed. The results from both methods gave qualitatively similar findings and therefore only the OLS regression output is presented in this paper. However, the results of the ordered logistic regression analysis are available from the author upon request.
} 
Table 9

OLS Regression of Financial Knowledge Score ${ }^{5}$

\begin{tabular}{lcc}
\hline \hline & Coefficient & $\begin{array}{c}\text { Standard } \\
\text { Error }\end{array}$ \\
\hline Age & $-0.016^{* * *}$ & $(0.006)$ \\
Age $^{2}$ & $<0.001 * *$ & $(<0.001)$ \\
Marital status = Married & $-<0.001$ & $(0.016)$ \\
Gender: Male = 1; Female =0 & $0.070^{* * * *}$ & $(0.015)$ \\
Race: Coloured & $-0.106^{* * *}$ & $(0.019)$ \\
Race: African & $-0.160^{* * *}$ & $(0.029)$ \\
Race: Indian & $-0.081^{* *}$ & $(0.034)$ \\
Race: Other & -0.066 & $(0.051)$ \\
Log COE & $0.137 * * *$ & $(0.019)$ \\
Qualification: Unknown & $0.056^{* *}$ & $(0.026)$ \\
Qualification: Tertiary<Honours & 0.032 & $(0.025)$ \\
Qualification: Tertiary $>$ Honours & $0.069 * *$ & $(0.028)$ \\
Constant & $-0.791 * * *$ & $(0.261)$ \\
Observations & 753 & \\
R-squared & 0.384 & \\
\hline \hline
\end{tabular}

Notes: $* * * p<0.01, * * p<0.05, * p<0.1$

${ }^{+}$Given the large range in $\mathrm{COE}$ of respondents, this variable was logged to allow for more substantive analysis, i.e., the interpretation of the change is multiplicative, rather than additive.

Upon assessment of the OLS results in Table 9, the statistically significant factors affecting financial knowledge are: age, gender, race, cost of employment, and level of education. As a respondent ages, his or her financial knowledge score decreases up until the age of 49 years. Thereafter, the predicted financial score increases as the respondent ages. It is noted that the coefficients of these two variables in Table 9 are small and thus the grade of slope is small. For example, the youngest person in the sample is 24 years old. The predicted difference in score between these two ages is only one-tenth of one question. This is in line with slight differences found by FSB (2016) across age. The economic significance of age on financial knowledge is small.

Given that the reference racial group is White, the results show that being of another racial group is associated with a lower financial knowledge score (1 to 2.4 fewer correct answers out of a total of 15). The African racial group has the largest negative coefficient on financial knowledge, and the difference is significant at the $1 \%$ level. Thus, even after controlling for other factors, race seems to matter to financial literacy, and we are left to consider potential reasons discussed earlier.

5 Table 9 presents the output on the unadjusted sample of respondents. The testing on the weighted sample (by racial grouping and education level) presented largely similar results, with no change in the direction, size, or level of statistical significance of the coefficients. 
These results are consistent with those reported by prior work in South Africa (FSB 2016) and in the United States (Lusardi and Mitchell 2011).

While the effect sizes for gender are also small, the results show that being male, as opposed to female, is correlated with higher financial knowledge scores. These gender differences are consistent with research performed around the world (Lusardi and Mitchell 2011; FSB 2012; Xu and Zia 2012). Furthermore, Willows and West (2015) reported that women (who are more risk-averse than men [Willows and West 2012]) are less prone to trading. It is suggested that the possible reluctance by women to engage in financial practices is a hindrance to their development of improved financial knowledge. This is a proposed area for further research.

Having a higher cost of employment is associated with greater financial knowledge. In the United States, Agnew and Szykman (2005) also reported higher levels of financial knowledge amongst those participants with higher salary levels and also noted larger size effects than with the other variables tested. It is suggested that the higher the income of an individual, the greater the responsibility to understand financial concepts to effectively manage that income becomes.

Table 9 also shows a positive relationship between an individual's level of qualification and his or her financial knowledge score. However, even with a small effect, this finding is only statistically significant when that education level is at an Honours tertiary degree level or higher. This finding is consistent with findings in FSB (2012) that those with lower levels of education have lower financial literacy. This association may be explained by Cole et al. (2012) who find that an extra year of education increases financial market participation by 7 to 8 percent. This suggests possible self-learning where individuals gain financial knowledge by operating with financial instruments. This supposition is another proposed area for future research.

\section{Self-Assessment of Financial Knowledge}

Given that proper self-awareness is required to know whether further improvement in financial knowledge is necessary, an understanding of whether respondents' selfassessed level of financial knowledge is correlated with their financial knowledge score is required. Respondents were asked to assess their own level of financial knowledge on a scale from 1 to 7 , with 1 being "very low" and 7 being "very high." 
Willows: Financial Literacy among Employees of a South African University

Table 10

Distribution of Self-Assessment Rating by Socioeconomic and Demographic Subgroup

\begin{tabular}{|c|c|c|c|c|c|c|c|c|c|c|c|}
\hline & 1 & 2 & 3 & 4 & 5 & 6 & 7 & $\operatorname{Mean}^{+}$ & SD & $F$ Statistic & $\begin{array}{c}\text { Correlation to Financial } \\
\text { Knowledge Score }\end{array}$ \\
\hline Total sample $(n=752)^{\#}$ & $3.4 \%$ & $8.3 \%$ & $12.3 \%$ & $38.4 \%$ & $22.9 \%$ & $11.8 \%$ & $2.7 \%$ & 4.2 & 1.3 & & $0.45^{* * *}$ \\
\hline Age & & & & & & & & & & 0.10 & \\
\hline$<=50(n=416)$ & $3.8 \%$ & $8.7 \%$ & $11.5 \%$ & $39.9 \%$ & $21.4 \%$ & $11.3 \%$ & $3.4 \%$ & 4.1 & 1.3 & & $0.47 * * *$ \\
\hline Age $>50 \quad(n=336)$ & $3.0 \%$ & $8.0 \%$ & $13.4 \%$ & $36.6 \%$ & $24.7 \%$ & $12.5 \%$ & $1.8 \%$ & 4.2 & 1.3 & & $0.43 * * *$ \\
\hline Gender & & & & & & & & & & $18.93 * * *$ & \\
\hline Male $(n=280)$ & $2.5 \%$ & $7.5 \%$ & $9.3 \%$ & $32.9 \%$ & $25.8 \%$ & $17.9 \%$ & $3.9 \%$ & 4.4 & 1.3 & & $0.51 * * *$ \\
\hline Female $(n=473)$ & $4.0 \%$ & $8.9 \%$ & $14.2 \%$ & $41.7 \%$ & $21.2 \%$ & $8.2 \%$ & $1.9 \%$ & 4.0 & 1.3 & & $0.38^{* * *}$ \\
\hline Race & & & & & & & & & & $8.45 * * *$ & \\
\hline White $(n=374)$ & $1.6 \%$ & $8.3 \%$ & $11.5 \%$ & $31.3 \%$ & $26.5 \%$ & $16.8 \%$ & $4.0 \%$ & 4.4 & 1.3 & & $0.48^{* * *}$ \\
\hline Coloured $(n=262)$ & $4.2 \%$ & $7.3 \%$ & $13.4 \%$ & $46.2 \%$ & $21.8 \%$ & $6.1 \%$ & $1.1 \%$ & 4.0 & 1.2 & & $0.32 * * *$ \\
\hline African $(n=72)$ & $9.7 \%$ & $16.7 \%$ & $13.9 \%$ & $37.5 \%$ & $12.5 \%$ & $8.3 \%$ & $1.4 \%$ & 3.6 & 1.5 & & $0.34 * * *$ \\
\hline Indian $(n=36)$ & $5.6 \%$ & $2.8 \%$ & $13.9 \%$ & $47.2 \%$ & $16.7 \%$ & $11.1 \%$ & $2.8 \%$ & 4.1 & 1.3 & & $0.55^{* * *}$ \\
\hline Other $(n=8)$ & $0.0 \%$ & $0.0 \%$ & $0.0 \%$ & $87.5 \%$ & $12.5 \%$ & $0.0 \%$ & $0.0 \%$ & 4.1 & 0.4 & & 0.32 \\
\hline Education ${ }^{\&}$ & & & & & & & & & & $5.29 * * *$ & \\
\hline Secondary $(n=115)$ & $5.2 \%$ & $9.6 \%$ & $16.5 \%$ & $42.6 \%$ & $22.6 \%$ & $2.6 \%$ & $0.9 \%$ & 3.8 & 1.2 & & $0.41 * * *$ \\
\hline Tertiary $(<$ Honours $)(n=217)$ & $2.8 \%$ & $4.6 \%$ & $15.2 \%$ & $41.5 \%$ & $19.4 \%$ & $13.4 \%$ & $3.2 \%$ & 4.2 & 1.2 & & $0.45^{* * *}$ \\
\hline Tertiary ( $>=$ Honours $)(n=327)$ & $1.5 \%$ & $9.8 \%$ & $10.4 \%$ & $32.7 \%$ & $26.3 \%$ & $15.6 \%$ & $3.7 \%$ & 4.3 & 1.3 & & $0.45^{* * *}$ \\
\hline Unknown ( $n=93)$ & $9.7 \%$ & $10.8 \%$ & $7.5 \%$ & $46.2 \%$ & $19.4 \%$ & $6.5 \%$ & $0.0 \%$ & 3.7 & 1.3 & & $0.38^{* * *}$ \\
\hline Marital Status & & & & & & & & & & 2.36 & \\
\hline Married $(n=525)$ & $2.9 \%$ & $7.6 \%$ & $13.5 \%$ & $37.3 \%$ & $23.2 \%$ & $12.4 \%$ & $3.0 \%$ & 4.2 & 1.3 & & $0.48^{* * *}$ \\
\hline Single $(n=227)$ & $4.8 \%$ & $10.1 \%$ & $9.7 \%$ & $41.0 \%$ & $22.0 \%$ & $10.6 \%$ & $1.8 \%$ & 4.0 & 1.3 & & $0.37 * * *$ \\
\hline Cost of employment & & & & & & & & & & $31.37 * * *$ & \\
\hline$<$ R 400,000 p.a. $(n=358)$ & $5.3 \%$ & $9.2 \%$ & $14.8 \%$ & $43.3 \%$ & $19.0 \%$ & $7.3 \%$ & $1.1 \%$ & 3.9 & 1.3 & & $0.32 * * *$ \\
\hline$>$ R400,000 p.a. $(n=394)$ & $1.8 \%$ & $7.6 \%$ & $10.2 \%$ & $34.0 \%$ & $26.4 \%$ & $16.0 \%$ & $4.1 \%$ & 4.4 & 1.3 & & $0.50 * * *$ \\
\hline
\end{tabular}


Table 10 reports the distributions of these self-assessments by socioeconomic and demographic subgroup. Similar to Table 8, the second-to-last column includes the $\mathrm{F}$ statistic from a single-factor ANOVA analysis testing equality of means across subgroups. ${ }^{6}$ The null hypothesis for each analysis is that the means of the individual groups are equal. The last column presents the correlation between selfassessments of financial knowledge and the measured financial knowledge scores.

The results show that the largest proportion of respondents rate their level of financial knowledge as "average." These results are contrary to what the behavioural literature refers to as the "better-than-average" effect (Landier and Thesmar 2008) or the converse-pessimism bias (Dowie and Willows 2015). Furthermore, there is a statistically significant positive but weak correlation $(0.45)$ between perceived and measured financial knowledge.

It is noticeable that men tend to rate their own perceived level of financial knowledge on a higher scale than women. This difference is statistically significant at the $1 \%$ level. Almost half of men $(47.6 \%)$ rated themselves as above average and higher, while only a third $(31.3 \%)$ of women responded similarly. Furthermore, men have a higher, although moderate, correlation (0.51) between their perceived and measured financial knowledge, than women do (0.38). This finding suggests that the differences in perceived financial literacy between men and women reported in Table 10 may not simply be a difference in confidence.

The same disparities that were seen in the financial knowledge scores of respondents of different races, education level, and COE are also seen with their perception of their own financial knowledge. Between the different racial groups, $40.3 \%$ of African respondents rated themselves as having below-average or lower financial knowledge, whereas only $21.4 \%$ of White respondents made that same self-assessment. Those respondents with only a secondary level of education have a lower self-perceived financial knowledge, and those with the highest education ( $>=$ Honours) have a higher self-perceived financial knowledge. Respondents with earnings greater than R400,000 per annum also show a higher self-assessment rating of their financial knowledge, in comparison to those respondents earning less than R400,000 per annum. Furthermore, there is a weak positive correlation (0.32) between perceived and measured financial knowledge for this latter group.

In the sample as a whole and in socioeconomic and demographic subgroups, I find a positive but weak correlation between a respondent's self-assessed financial knowledge and his or her actual measured financial knowledge. While respondents appear to have some notion of their level of financial knowledge, they tend to slightly underestimate their financial knowledge.

${ }^{6}$ The author notes the potential problem with interpreting ordinal data as cardinal data for the purpose of this analysis. 


\section{Conclusions and Recommendations}

This study's assessment of the basic financial knowledge of respondents showed that most respondents were able to understand simple problems involving interest and the effects of inflation. Men, those respondents with higher earnings, or with a higher level of education had a larger proportion of correct answers than women and those with lower earnings or a lower level of education. Across racial groupings, White respondents showed a larger proportion of correct answers than African respondents, with the latter group being more inclined to indicate that they did not know the answer. An OLS regression analysis established the significance of the findings that age, male gender, White race, higher earnings, and greater education positively influence financial knowledge even after controlling for covariates.

While the mode financial knowledge self-assessment is "average," more noteworthy was that respondents were generally able to somewhat correctly assess their own level of financial knowledge. Those with less accurate beliefs showed an underestimation in their self-assessments. Whether individuals are of the belief that they need to improve their financial knowledge or not is one thing, but at the very least they are to some extent likely to be aware of their own shortcomings in this regard.

The results from the testing highlight that, while some differences in the level of financial knowledge of respondents of different socioeconomic characteristics exist, these differences are modest at best. Rather, all the respondents require further advancement in their financial knowledge. This finding is particularly notable given that the sample tested is drawn from generally highly-educated individuals working for an employer implementing many best practices in supporting employees' financial planning. Therefore, these practices on their own are insufficient to achieve financial literacy. That being said, financial education should not be generic, but rather appropriately designed to achieve maximum impact for its target audience. As an example, with women testing as less financially knowledgeable than men, careful consideration should be given to market training courses to women, tailor examples and scenarios specific to women, and in so doing, reduce the financial knowledge gap between men and women without limiting further advancement in the financial knowledge of men. These findings are useful, as practical steps will be more beneficial when tailored to a type of individual rather than generalising across a population.

However, further research is required to understand the most appropriate means to financially educate individuals of different socioeconomic backgrounds. Qualitative research would be useful in assessing cultural and societal differences amongst the population. This should assist in deciding on the best approach to 
enable all individuals or communities to make suitable savings decisions and allow for improved financial responsibility amongst all.

\section{Acknowledgements}

The work is based on the research supported in part by the National Research Foundation of South Africa for the grant, Unique Grant No. 94145.

\section{References}

Agnew, Julie, Hazel Bateman, and Susan Thorp. 2013. "Financial Literacy and Retirement Planning in Australia." Numeracy 6 (2): Article 7. https://doi.org/10.5038/1936-4660.6.2.7.

Agnew, Julie, and Lisa R Szykman. 2005. "Asset Allocation and Information Overload: The Influence of Information Display, Asset Choice, and Investor Experience." The Journal of Behavioral Finance 6 (2): 57-70. https://doi.org/10.1207/s15427579jpfm0602__2.

Arrondel, Luc, Majdi Debbich, and Frederique Savignac. 2013. "Financial Literacy and Financial Planning in France." Numeracy 6 (2): Article 8.

Atkinson, Adele, and FloreAnne Messy. 2012. "Measuring Financial Literacy: Results of the OECD / International Network on Financial Education (INFE) Pilot Study." OECD Working Papers on Finance, Insurance and Private Pensions, no. 15: 1-73. https://doi.org/10.1787/5k9csfs90fr4-en.

Beckmann, Elisabeth. 2013. "Financial Literacy and Household Savings in Romania." Numeracy 6 (2): Article 9. https://doi.org/10.5038/19364660.6.2.9.

Brown, Martin, and Roman Graf. 2013. "Financial Literacy and Retirement Planning in Switzerland.” Numeracy 6 (2): Article 6. https://doi.org/10.5038/1936-4660.6.2.6.

Cole, Shawn, Anna Paulson, and Gauri Kartini Shastry. 2012. "Smart Money: The Effect of Education on Financial Behavior."

Dowie, G, and G Willows. 2015. "An Investigation of Investors' Estimates of Returns Earned and the Effect of Anchoring on These Estimations." South African Journal of Accounting Research, May: 1-12. https://doi.org/10.1080/10291954.2015.1021559.

Financial Services Board. 2012. "Financial Literacy in South Africa: Results of a National Baseline Survey." https://www.fsb.co.za/Departments/consumerEducation/Documents/Financial Literacy Booklet 2012.pdf.

Financial Services Board. 2016. "Financial Literacy in South Africa: Results from the 2015 South African Social Attitudes Survey (SASAS) Round." 
https://www.mylifemymoney.co.za/Resources/Research Documents/FSB Financial Literacy Report 2015.pdf.

Fomero, Elsa, and Chiara Monticone. 2011. "Financial Literacy and Pension Plan Participation in Italy." Journal of Pension Economics and Finance 10 (4): 547-564. https://doi.org/10.1017/S1474747211000473.

Klapper, Leora, and Georgios A. Panos. 2011. "Financial Literacy and Retirement Planning: The Russian Case." Journal of Pension Economics and Finance 10 (4): 599-618. https://doi.org/10.1017/S1474747211000503.

Landier, A., and D. Thesmar. 2008. "Financial Contracting with Optimistic Entrepreneurs." Review of Financial Studies 22 (1): 117-150. https://doi.org/10.1093/rfs/hhn065.

Lusardi, Annamaria, and Olivia S. Mitchell. 2011. "Financial Literacy and Planning: Implications for Retirement Wellbeing." Financial Literacy, Implications for Retirement Security and the Financial Marketplace, Oxford: Oxford University Press: 17-39. https://doi.org/10.1093/acprof:oso/9780199696819.003.0002.

Lusardi, Annamaria, and Olivia S. Mitchell. 2014. "The Economic Importance of Financial Literacy : Theory and Evidence." Journal of Economic Literature 52 (1): 5-44. https://doi.org/10.1257/jel.52.1.5.

Lusardi, Annamaria, and Olivia S. Mitchell. 2017. "How Ordinary Consumers Make Complex Economic Decisions: Financial Literacy and Retirement Readiness." Quarterly Journal of Finance 7 (3): 1750008. https://doi.org/10.1142/S2010139217500082.

Old Mutual. 2013. "South Africa: This Is What Your Retirement Looks Like." Old Mutual Retirement Monitor, 1-47.

Olsen, Anya, and Kevin Whitman. 2007. "Effective Retirement Savings Programs: Design Features and Financial Education." Social Security Bulletin 67 (3): 53-72.

Sekita, Shizuka. 2011. "Financial Literacy and Retirement Planning in Japan." Journal of Pension Economics and Finance 10 (4): 637-56. https://doi.org/10.1017/S1474747211000527.

Shefrin, Hersh. 2013. "Born To Spend? How Nature and Nurture Impact Spending and Borrowing Habits." Chase Blueprint. https://www.chase.com/online/chase_blueprint/document/JPMC_Chase_Born ToSpend_FINAL.pdf.

Smith, Terry. 2017. "The Unique Advantage of Equity Investment." Fin24.com. https://www.fin24.com/Finweek/Investment/the-unique-advantage-of-equityinvestment-20170830.

Spaull, Nic. 2015. "Schooling in South Africa: How Low Quality Education Becomes a Poverty Trap." In South African Child Gauge 12: 34-41. 
Van Rooij, Maarten, Annamaria Lusardi, and Rob Alessie. 2011. "Financial Literacy and Stock Market Participation." Journal of Financial Economics 101: 449-472. https://doi.org/10.1016/j.jfineco.2011.03.006.

Willows, Gizelle, and Darron West. 2012. "Differential Investment Performance Based on Gender : A Review of Literature." SAAA Western Cape Regional Conference: Peer-Reviewed Conference Proceedings, 72-95. Cape Town, South Africa: Southern African Accounting Association.

Willows, Gizelle, and Darron West. 2015. "Differential Investment Performance In South Africa Based On Gender." International Business \& Economics Research Journal 14 (1): 221-36. https://doi.org/10.19030/iber.v14i3.9215.

$\mathrm{Xu}$, Lisa, and Bilal Zia. 2012. "Financial Literacy Around the World: An Overview of the Evidence with Practical Suggestions for the Way Forward." Policy Research Working Paper, no. 6107: 1-56. https://doi.org/10.1596/1813-9450-6107. 


\section{Appendix A: Financial Knowledge Questions}

The following questions are designed to assess an individual's basic financial literacy (Questions 1-4) and advanced financial knowledge (Questions 5-15).

\begin{tabular}{|c|c|c|}
\hline Numeracy & $\begin{array}{l}\text { Q1 Suppose you had R100 in a savings account and the } \\
\text { interest rate was } 2 \% \text { per year. After } 5 \text { years, how much do you } \\
\text { think you would have in the account if you left the money to } \\
\text { grow? } \\
\text { More than R102 } \\
\text { Exactly R102 } \\
\text { Less than R102 } \\
\text { Do not know }\end{array}$ & $\begin{array}{l}\text { (Lusardi and Mitchell } \\
\text { 2011) }\end{array}$ \\
\hline Inflation & $\begin{array}{l}\text { Q2 Imagine that the interest rate on your savings account was } \\
1 \% \text { per year and inflation was } 2 \% \text { per year. After } 1 \text { year, how } \\
\text { much would you be able to buy with the money in this } \\
\text { account? } \\
\text { More than today } \\
\text { Exactly the same } \\
\text { Less than today } \\
\text { Do not know }\end{array}$ & $\begin{array}{l}\text { (Lusardi and Mitchell } \\
\text { 2011) }\end{array}$ \\
\hline Time value of money & $\begin{array}{l}\text { Q3 Assume a friend inherits R } 10,000 \text { today and his brother } \\
\text { inherits R } 10,0003 \text { years from now. Who is richer because of } \\
\text { the inheritance? } \\
\text { My friend } \\
\text { His brother } \\
\text { They are equally rich } \\
\text { Do not know }\end{array}$ & $\begin{array}{l}\text { (Lusardi and Mitchell } \\
\text { 2017), "sibling" changed } \\
\text { to "brother" for } \\
\text { clarification }\end{array}$ \\
\hline Money illusion & $\begin{array}{l}\text { Q4 Suppose that in the year 2020, your income has doubled } \\
\text { and prices of all goods have doubled too. In } 2020 \text {, how much } \\
\text { will you be able to buy with your income? } \\
\text { More than today } \\
\text { The same as today } \\
\text { Less than today } \\
\text { Do not know }\end{array}$ & $\begin{array}{l}\text { (Lusardi and Mitchell } \\
\text { 2017) }\end{array}$ \\
\hline $\begin{array}{l}\text { Function of the share } \\
\text { market }\end{array}$ & $\begin{array}{l}\text { Q5 Which of the following statements describes the main } \\
\text { function of the share market (also referred to as the "stock } \\
\text { market" or "equity market")? } \\
\text { The share market helps to predict share earnings } \\
\text { The share market results in an increase in the price of shares } \\
\text { The share market brings people who want to buy shares } \\
\text { together with those who want to sell shares } \\
\text { None of the above } \\
\text { Do not know }\end{array}$ & $\begin{array}{l}\text { (Lusardi and Mitchell } \\
\text { 2017), "stock" } \\
\text { (American terminology) } \\
\text { replaced with "share" } \\
\text { (South African } \\
\text { terminology), and } \\
\text { further examples given } \\
\text { to ensure clarity }\end{array}$ \\
\hline Knowledge of shares & $\begin{array}{l}\text { Q6 Which of the following statements is correct? If somebody } \\
\text { buys a share of company B in the share market: } \\
\text { He owns a part of company B } \\
\text { He has loaned money to company B } \\
\text { He is liable for company B's debts } \\
\text { None of the above } \\
\text { Do not know }\end{array}$ & (Van Rooij et al. 2011) \\
\hline
\end{tabular}


Knowledge of collective investment schemes

Knowledge of bonds

Long-period returns

Highest variability

Risk diversification

Bond principles
Q7 Which of the following statements is most correct? Once you invest in a collective investment scheme, i.e., "unit trust," you cannot withdraw the money in the first year Unit trusts can invest in several asset classes, for example; shares/equity, bonds, property, and cash.

Unit trusts pay a guaranteed rate of return which depends on their past performance

None of the above

Do not know

Q8 Which of the following statements is correct? If somebody buys a bond issued by company $\mathrm{B}$ :

He owns a part of company B

He has loaned money to company B

$\mathrm{He}$ is liable for company B's debts

None of the above

Do not know

Q9 Considering a long time period (for example 10 or 20 years), which asset normally gives the highest return? Savings accounts / Cash

Bonds

Shares / Equity

Do not know

Q10 Normally, which asset displays the highest variability of return over time?

Savings accounts / Cash

Bonds

Shares / Equity

Do not know

Q11 Complete the sentence. When an investor spreads his or her money among different assets, the risk of losing money should:

Increase

Decrease

Stay the same as if the investor hadn't spread his or her money Do not know

Q12 True or false? If you buy a 10-year bond, it means you cannot sell it after 5 years without incurring a major penalty.

True

False

Do not know

Q13a True or false? Equity/shares are normally riskier than bonds.

True

False

Do not know

OR

Q13b True or false? Bonds are normally riskier than shares/equity.

True

False

Do not know
(Lusardi and Mitchel 2017), "mutual fund"

(American terminology) replaced with "collective investment scheme" (South African terminology), and lay terminology of "unit trust" also given to ensure clarity

(Van Rooij et al. 2011)

(Lusardi and Mitchel 2017), multiple terms for cash and equity given to ensure clarity

(Lusardi and Mitchell 2017), multiple terms for cash and equity given to ensure clarity

(Lusardi and Mitchell 2017), response for "stay the same" extended to make complete sentence

(Van Rooij et al. 2011)

(Lusardi and Mitchell 2017), multiple terms for equity given to ensure clarity 
Q14a True or false? Buying a share of an individual company usually provides a safer return than a general equity unit trust.

True

False

Do not know

OR

Q14b True or false? Buying a general equity unit trust usually provides a safer return than a share of an individual company.

True

False

Do not know

Q15a If the interest rate rises, what should happen to bond prices?

Rise

Fall

Stay the same

None of the above

Do not know

OR

Q15b If the interest rate falls, what should happen to bond prices?

Rise

Fall

Stay the same

None of the above

Do not know
(Lusardi and Mitchell 2017), "mutual fund" (American terminology) replaced with "unit trust" (South African terminology)

(Lusardi and Mitchell 2017) 